\title{
ANALISIS PENGUJIAN DRY GAS SEAL TYPE 28AT TANDEM UNTUK MENINGKATKAN RELIABILITY DRY GAS SEAL DI KOMPRESOR SENTRIFUGAL
}

\author{
Nuradi ${ }^{1, *}$ \\ ${ }^{1}$ Teknik Mesin, Fakultas Teknologi Industri, Universitas Tama Jagakarsa \\ J1. TB Simatupang No. 152 Tanjung Barat, Jakarta Selatan 12530 \\ *E-mail: nuradi@jagakarsa.ac.id
}

\begin{abstract}
ABSTRAK
Pengujian dry gas seal adalah salah satu tahapan dalam perbaikan dan pemeliharaan dry gas seal, karena tanpa adanya pengujian dry gas seal akan berakibat fatal, bisa menimbulkan kerusakan yang lebih parah di kompresor dan membahayakan manusia dan lingkungan. Dalam pengoperasian dan pemeliharaan kompresor sertifugal khususnya kompresor gas sering sekali terjadi kerusakan dry gas seal atau meskipun tidak rusak dry gas seal harus tetap di health check agar bisa digunakan dengan optimal dan keandalannya bisa meningkat. Dalam melakukan health check atau perbaikan dry gas seal salah satu penentu keberhasilannya adalah dengan melalui pengujian statis dan dinamis dengan menggunakan DGS test rig atau sejenisnya. Oleh karena sangat pentingnya dalam pengujian dry gas seal ini penulis mencoba meneliti bagaimana tahapan-tahapan yang harus diperhatikan dalam prosedur pengujian. Dalam penelitian ini dapat disimpulkan bahwa kecepatan maksimum yang digunakan mencapai $11.429 \mathrm{rpm}$, jika dibandingkan dengan prosedur adalah $1-1.225 \mathrm{x}$ rpm di kompresor, maka rotasi yang diperoleh sesuai prosedur adalah $(1.225 \times 10.000=$ maksimum $12250 \mathrm{rpm})$, dengan kondisi $11429 \mathrm{rpm}$ sudah memenuhi standar dan masih dalam toleransi putaran pengujian.
\end{abstract}

Kata kunci: dry gas seal; kompresor sentrifugal; pengujian statis dan dinamis.

\section{ABSTRACT}

Dry gas seal testing is one of the stages in the repair and maintenance of dry gas seals because without testing dry gas seals will have fatal consequences, which can cause more severe damage to the compressor and repair of humans and the environment. In the operation and maintenance of centrifugal compressors, especially gas compressors, there is often damage to dry gas seals or even if they are not damaged dry gas seals must be kept in a health check so that they can be used optimally and their reliability can be improved. In conducting a health check or repairing dry gas seal, one of the determinants of success is through static and dynamic testing using the DGS test rig or the other. Therefore it is very important in testing this dry gas seal that the author tries to learn how to complete the tests that must be considered in the testing procedure. In this study it can be concluded that the maximum speed used reaches $11429 \mathrm{rpm}$, when compared to the procedure is 1-1,225 x rpm in the compressor then the rotation obtained according to the procedure is $(1,225 \times 10000=12250 \mathrm{rpm}$ maximum), with conditions $11429 \mathrm{rpm}$ already fulfilling standard and is still within tolerance of testing rounds.

Keywords: dry gas seals; centrifugal compressors; static and dynamic testing. 


\section{PENDAHULUAN}

Penggunaan dry gas seal (seal gas kering) dalam kompresor sentrifugal gas proses telah meningkat secara dramatis selama dua puluh tahun terakhir, menggantikan seal film minyak tradisional dalam sebagian besar aplikasi. Lebih dari $80 \%$ kompresor gas sentrifugal yang diproduksi saat ini dilengkapi dengan dry gas seal. Karena dry gas seal telah diterima oleh pengguna dan pabrikan peralatan asli kompresor sentrifugal (OEM), dikarenakan pengoperasiannya terus-menerus diperbarui [1].

Permintaan yang semakin besar pada dry gas seal dan sistem pendukungnya, yang membutuhkan perbaikan berkelanjutan dalam desain lingkungan dry gas seal, baik internal maupun eksternal untuk kompresor yang tepat. Pengujian dry gas seal adalah salah satu tahapan dalam perbaikan dan pemeliharaan $d r y$ gas seal, karena tanpa adanya pengujian dry gas seal akan berakibat fatal, bisa menimbulkan kerusakan yang lebih parah di kompresor dan membahayakan manusia dan lingkungan $[2,3]$.

Dry gas seal dapat menghilangkan beberapa masalah konvensional yang terkait dengan sistem seal minyak. Peningkatan keselamatan, penurunan pemeliharaan, dan peningkatan keandalan adalah pertimbangan utama untuk kekuatan gas seal. Memahami teknologi seal gas kering dan mengoptimalkan pemilihan seal untuk sekumpulan parameter operasi tertentu sangat penting untuk keberhasilan aplikasi peralatan rotasi. Sistem kontrol yang menggabungkan filtrasi, kebocoran, dan pemantauan tekanan dapat memberikan diagnosis waktu kinerja seal yang nyata [4].

Kompresor sentrifugal dalam layanan gas proses memerlukan penyegelan poros untuk mencegah gas proses keluar dari casing kompresor yang tidak terkendali, ke atmosfer. Multi stage kompresor tipe "beam" membutuhkan dua seal, satu di setiap dan dari poros. Kompresor tipe overhung satu tahap membutuhkan seal poros tunggal, tepat di belakang impeller. Dry Gas Seal dapat diterapkan untuk mencapai penyegelan poros yang diperlukan [5].

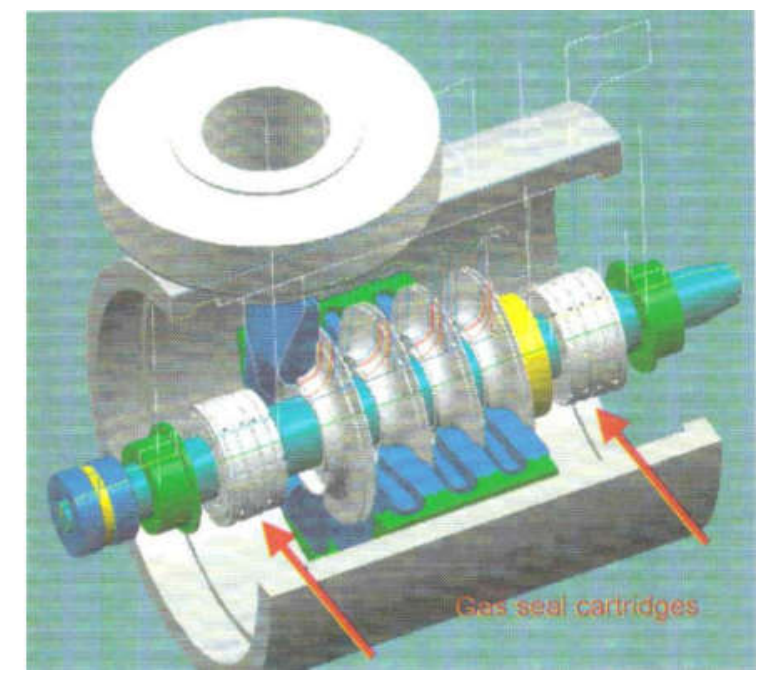

Gambar 1. Lokasi dari Shaft Seals

Dry gas seal tersedia dalam berbagai konfigurasi, tetapi gaya "tandem" biasanya diterapkan dalam layanan gas proses (gambar 2). Seal tandem terdiri dari seal primer dan seall sekunder, yang terkandung dalam satu catridge. Selama operasi normal, seal primer menyerap penurunan tekanan total ke sistem ventilasi, dan seal sekunder berfungsi sebagai cadangan jika seal primer gagal.

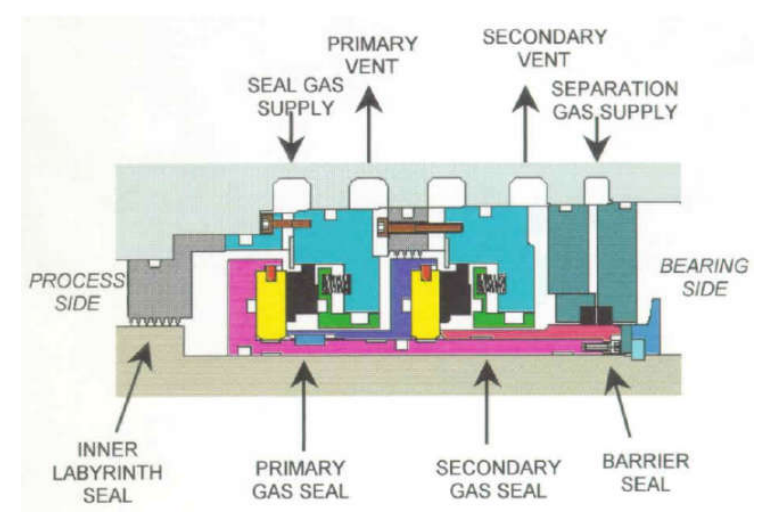

Gambar 2. Type Tandem Gas Seal / Konfigurasi barrier seal

Desain seal gas yang dibahas di sini adalah jenis alur spiral. Berbagai jenis konfigurasi face telah diusulkan oleh beberapa produsen selama lima belas tahun terakhir. Desain konfigurasi permukaan alur spiral adalah salah satu yang telah berhasil dikembangkan dan diterapkan pada peralatan kompresor 
sentrifugal. Upaya telah dilakukan untuk memberikan beberapa kriteria desain seal, berbagai jenis pengaturan seal dan untuk menekankan perlunya pemilihan seal yang optimal dan pemilihan sistem kontrol. Kondisi proses, yaitu tekanan, suhu, komposisi gas, dan kontaminan dalam aliran gas adalah bagian integral dari proses desain seal. Dan yang tidak kalah pentingnya adalah karakteristik utama dari peralatan kompresi yang terlibat, yaitu kenaikan suhu dari hisap ke pelepasan, kecepatan permukaan yang terlibat, baik itu overhung atau beam unit, dan rotor dynamic.

Tinjauan lokasi peralatan kompresi dalam keseluruhan loop proses dapat memberikan informasi penting tentang kontaminan dalam aliran gas. Ulasan P\&ID dapat memberikan alternatif pilihan pasokan gas buffer untuk seal. Di atas segalanya, perubahan dari sistem wet seal yang ada ke seal kering mungkin dapat berdampak efisiensi pabrik secara positif dengan menghilangkan kontaminasi minyak pada peralatan downstream, katalis, dan lainlain.

\section{METODE PENELITIAN}

\subsection{Diagram Alir Penelitian}

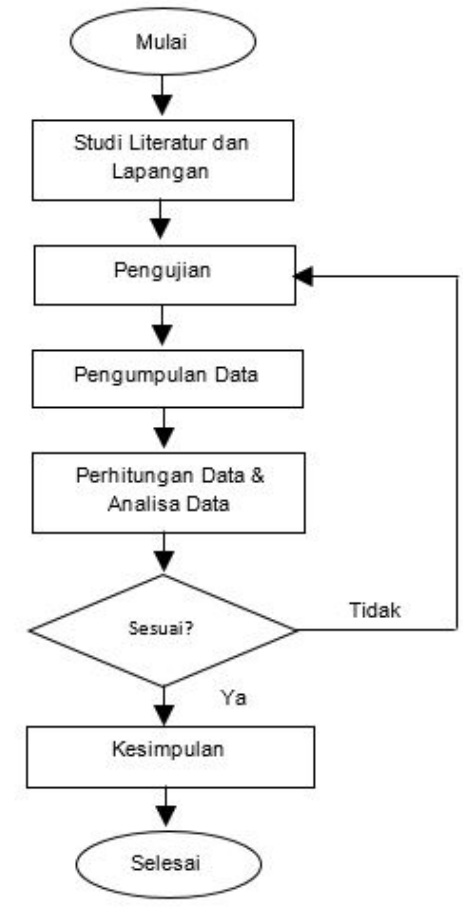

Gambar 3. Alur Penelitian
Metode ini menggunakan metode eksperimental yaitu dengan melakukan serangkaian pengujian pada dry gas seal tipe 28 AT Tandem dengan menggunakan test cell yang disesuaikan dengan housing DGS pada kompresor sentrifugal.

\subsection{Skema Alat Pengujian}

a. Desain Alat Uji Dry Gas Seal (DGS)

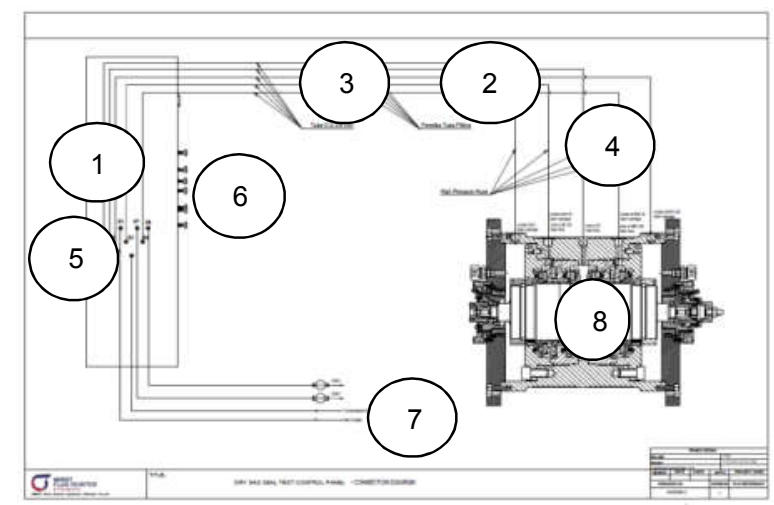

Gambar 4. Desain Alat Uji Dry Gas Seal (control panel connection).

Bagian-bagian alat uji (Test Rig DGS):

- Panel control DGS

- Tubing pipe

- Tubing connection

- High Pressure Hose

- Connection tube to DGS control module

- Regulator valve pressure

- Vent

- Test cell

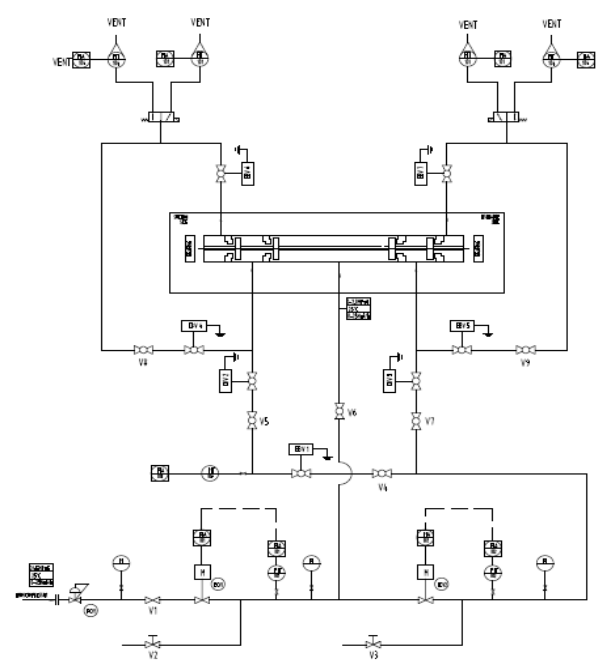

Gambar 5. Grafik P\&ID Control Module DGS 
b. Produk yang diuji

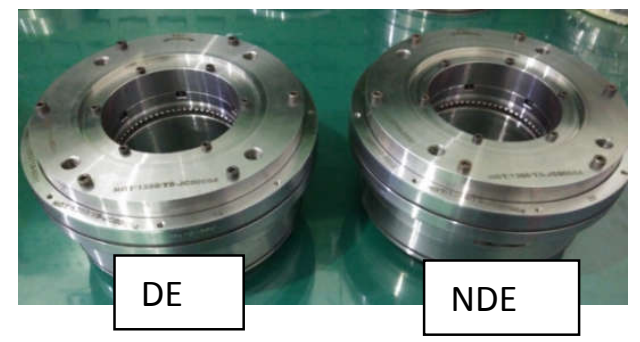

Gambar 6. Produk DGS type 28AT Tandem

c. Tes Assembly Drawing

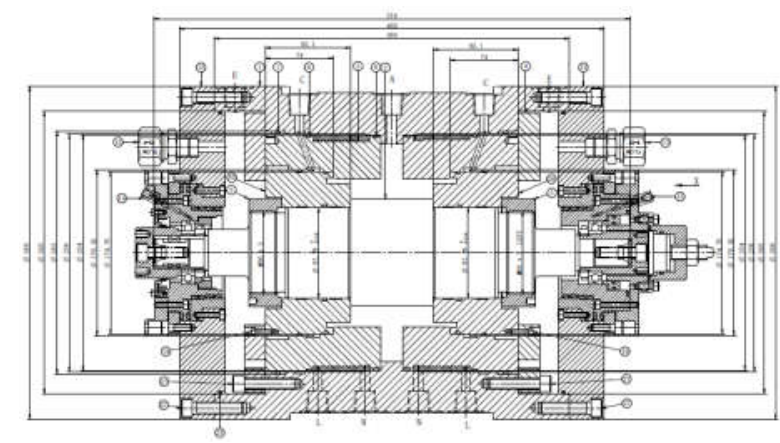

Gambar 7. Skema DGS yang sudah di Assembly

DGS yang sudah dirakit kemudian dimasukan ke dalam test cell dan akan di pasang di test rig/test bed.

\section{d. Monitoring Pengujian DGS}

Pengujian dry gas seal ini dikontrol melalui monitor yang sudah terkoneksi dengan internet sehingga proses data yang terjadi up to date. Baik itu untuk melakukan pengaturan maupun input data yang terbaru melalui kontrol dimonitor.

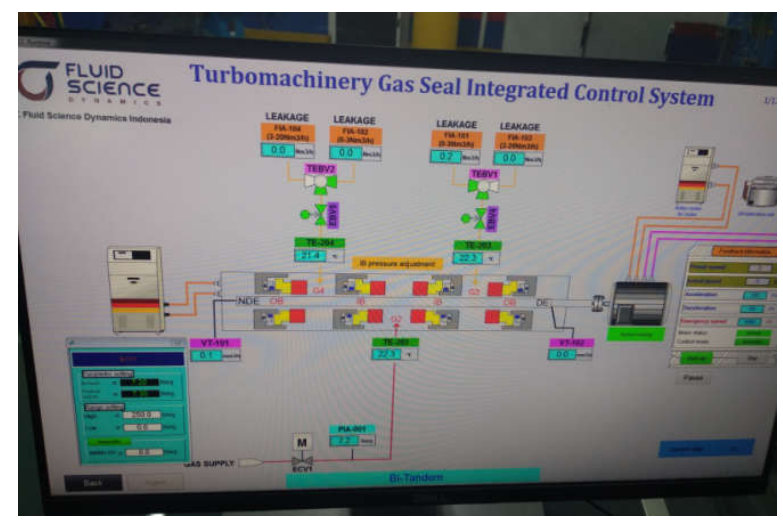

\subsection{Waktu dan Tempat Penelitian}

Pelaksanaan penelitian dilakukan pada tangal 16 Januari sampai 17 Januari 2019 di PT. Fluid Science Dynamics Indonesia. Pelaksanaan penelitian ini dilakukan dengan cara pengujian langsung terhadap apa yang akan dijadikan suatu penelitian serta wawancara langsung kepada Service engineer dari PT. Fluid Science Dynamics Indonesia demi mendapatkan hasil ataupun data yang akurat dari perusahaan.

\subsection{Pengumpulan Data}

Pengumpulan data bisa langsung dari pengamatan maupun data yang sudah tersedia di dalam perusahaan. Data yang ada akan dijadikan suatu acuan dalam pembahasan penelitian ini yang berguna untuk mendapatkan solusi ataupun alternatif lain yang lebih baik guna untuk meningkatkan kualitas dan efisiensi kerja.

\subsection{Prosedur Pengujian DGS}

Dalam melaksanakan pengujian dry gas seal harus mengikuti tahapan-tahapan yang sudah dibakukan dalam prosedur, hal ini dimaksudkan agar hasil yang didapatkan lebih akurat, konstan dan lebih memperhatikan aspek keselamatan kerjanya.

\section{a. Tahap Persiapan}

Sebelum pengujian dilakukan harus diperhatikan hal-hal sebagai berikut:

- Spesifikasi test ini harus disepakati antara Pembeli \& Penjual. Setelah disetujui, tidak ada revisi yang dapat dilakukan tanpa persetujuan formal lebih lanjut.

- Sebelum pengujian yang ditentukan dalam dokumen ini, prosedur kontrol kualitas berikut harus memuaskan pelanggan, diantaranya:

- Jaminan Kualitas Pemasok untuk komponen dan bahan yang disediakan

- Inspeksi komponen, dimensi dan visual optic

Gambar 8. Control Monitor DGS 
- Penyeimbangan (balancing) komponen berputar dengan menggunakan standar ISO 1940 G2.5

- Pengujian spin test untuk rotating seats ke 1.225xMax kecepatan kontinyu sampai 180 detik, sesuai dengan file Prosedur FSD.

- Semua seal yang disuplai dengan technical passport yang menyatakan kepatuhan dengan tindakan di atas.

- Pelanggan akan diberi tahu tanggal dan waktu menyaksikan pengujian, memberikan pemberitahuan sepuluh hari sebelumnya jika memungkinkan. Perkiraan total waktu tes harus diberitahukan. Pelanggan harus mengkonfirmasi identitas saksi sebelum kedatangan.

\section{b. Tahap Saat Pengujian}

Adapun kondisi saat pengujian harus diperhatikan hal-hal sebagai berikut:

- Rig uji harus dihubungkan secara umum sesuai dengan gambar rakitan uji. Gas uji akan mengalir ke test cell kecuali ada ketentuan lain.

- Pengujian akan dilakukan sesuai dengan Prosedur Uji.

- Operasi gas seal membutuhkan kebocoran kecil yang terkendali untuk memungkinkan pengeringan, semua pengukuran kebocoran akan dilakukan dalam kondisi kebocoran yang stabil.

- Jika suhu yang ditentukan, sulit untuk dicapai karena karakteristik pembangkitan panas rig/seal, kecepatan dan tekanan rig dapat disesuaikan untuk memberikan kondisi pengoperasian yang stabil.

- Pembacaan kebocoran outboard seal DE dapat terdistorsi oleh efek windage yang disebabkan oleh bantalan bola dan poros test cell. Jika kejadian ini tidak mungkin terjadi, kebocoran aktual outboard seal DE disimpulkan melalui korelasi terhadap seal NDE dengan dan tanpa tutup ujung.

- Data berikut akan diperoleh selama tes:

- Temperatur cell, inboard dan outboard

- Tekanan sel dan antar ruang

- Uji kecepatan
- Aliran kebocoran dari seal inboard (sisi proses) dan outboard (sisi atmosfer).

- Kondisi Operasi Lapangan Kompresor

Tes akan dianggap berhasil jika kriteria kebocoran berikut dipenuhi:

- Max Continuous Speed 12713 RPM

- Overspeed (110\%) 13984 RPM

- Static Pressure (100\%) 24,5 Bar (a)

- Dynamic Pressure $\underline{15,75}$ Bar (a)

- Max Seal Gas Temp $\underline{200}^{\circ} \mathrm{C}$

- Pengujian akan berhasil jika mengikuti kriteria kebocoran sebagai berikut :

Tabel 1. Parameter Pengaturan Pengujian

\begin{tabular}{rcc}
\hline Parameter & \multicolumn{3}{c}{ Nilai } \\
\hline Test Points & 68.1 & 27.54 \\
Inboard & 100 & 100 \\
Seal (\%) & & \\
Pressure & 24,5 & 15,75 \\
(Bar(g)) & & \\
Speed (\%) & 0 & 100 \\
RPM & 0 & 12713 \\
Maximum & & \\
Leakage & & \\
Inboard & 1,08 & 1,86 \\
Outboard & $<0,2$ & $<0,2$ \\
\hline
\end{tabular}

- Pemeriksaan visual harus dilakukan setelah pengujian.

Satu seal dari pasangan pertama yang diuji harus dibuka dan diperiksa secara visual. Setiap bukti tekanan mekanis atau termal (misalnya mencungkil, mematri panas) akan menghasilkan penolakan. Pemeriksaan lebih lanjut kemudian akan dilakukan, sekarang menggunakan perbesaran, sampai penerimaan teknis ditentukan, dan catatan dibuat dari log uji.

Goresan minor permukaan karbon pada permukaan dapat diterima jika seal pertama reject, sisa batch harus dibuka dan diperiksa. 


\section{HASIL DAN PEMBAHASAN}

Dari hasil pengujian dan analisis dry gas seal per sequence didapatkan hasil seperti pada tabel 2.

Tabel 2. Hasil Analisis Pengujian Dry Gas Seal

\begin{tabular}{|c|c|c|c|c|c|c|}
\hline Item & SQ1 & SQ2 & SQ3 & SQ4 & SQ5 & SQ6 \\
\hline RPM & 0 & 11429 & 10480 & 10441 & 10388 & 0 \\
\hline $\begin{array}{r}\text { Cell Press } \\
\text { (barg) }\end{array}$ & 10 & 6.67 & 9.1 & 9.09 & 9.09 & 10.39 \\
\hline $\begin{array}{r}\text { IB Press } \\
\text { DE (barg) } \\
\text { IB Press }\end{array}$ & 7.38 & 0 & 6.05 & 6.07 & 6.05 & 7.38 \\
\hline $\begin{array}{r}\text { NDE } \\
\text { (barg) }\end{array}$ & 7.38 & 0 & 6.05 & 6.07 & 6.05 & 7.38 \\
\hline $\begin{array}{r}\text { Temp Cell } \\
\left({ }^{\circ} \mathrm{C}\right)\end{array}$ & Ambient & 21.89 & 21.64 & 22.66 & 22.24 & Ambient \\
\hline $\begin{array}{r}\text { IB Temp } \\
\text { DE }\left({ }^{\circ} \mathrm{C}\right)\end{array}$ & Ambient & 21.71 & 21.59 & 22.16 & 22.26 & Ambient \\
\hline $\begin{array}{l}\text { IB Temp } \\
\operatorname{NDE}\left({ }^{\circ} \mathrm{C}\right)\end{array}$ & Ambient & 21.71 & 21.71 & 21.16 & 22.26 & Ambient \\
\hline $\begin{array}{r}\text { OB Temp } \\
\text { DE }\left({ }^{\circ} \mathrm{C}\right)\end{array}$ & Ambient & 23.26 & 23.26 & 22.89 & 22.97 & Ambient \\
\hline $\begin{array}{l}\text { OB Temp } \\
\operatorname{NDE}\left({ }^{\circ} \mathrm{C}\right)\end{array}$ & Ambient & 23.26 & 23.26 & 22.89 & 22.97 & Ambient \\
\hline $\begin{array}{r}\text { Leak DE IB } \\
(\mathrm{Nm} 3 / \mathrm{h}) \\
\text { Leak DE }\end{array}$ & 0.21 & 0.28 & 0.27 & 0.57 & 0.27 & 0.2 \\
\hline $\begin{array}{r}\mathrm{OB} \\
(\mathrm{Nm} 3 / \mathrm{h})\end{array}$ & 0 & 0 & 0 & 0 & 0 & 0 \\
\hline Leak NDE & & & & & & \\
\hline $\begin{array}{r}\text { IB } \\
(\mathrm{Nm} 3 / \mathrm{h})\end{array}$ & 0 & 0.28 & 0.24 & 0.44 & 0.26 & 0.2 \\
\hline Leak NDE & & & & & & \\
\hline $\begin{array}{r}\mathrm{OB} \\
(\mathrm{Nm} 3 / \mathrm{h})\end{array}$ & 0 & 0 & 0 & 0 & 0 & 0 \\
\hline
\end{tabular}

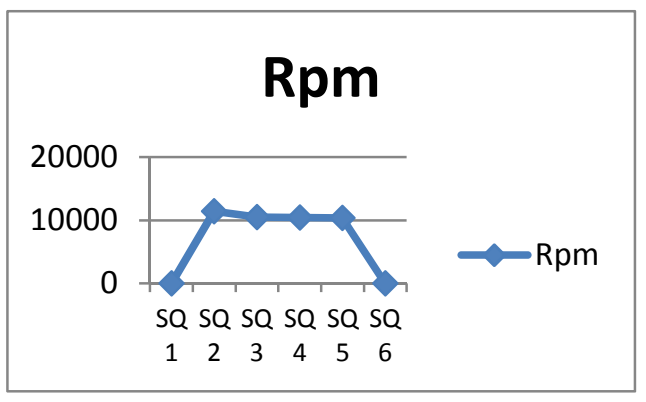

Gambar 9. Putaran maksimum Pengujian pada tiap Sequence

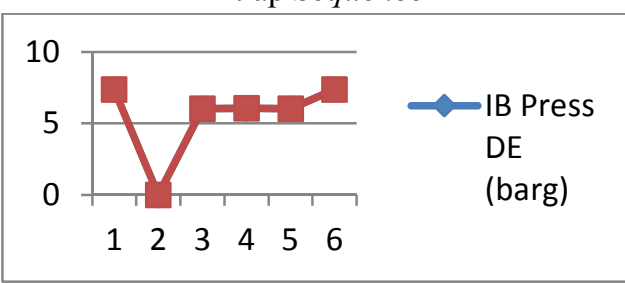

Gambar 10. Tingkat Pressure (tekanan) disisi Inboard DE \& NDE

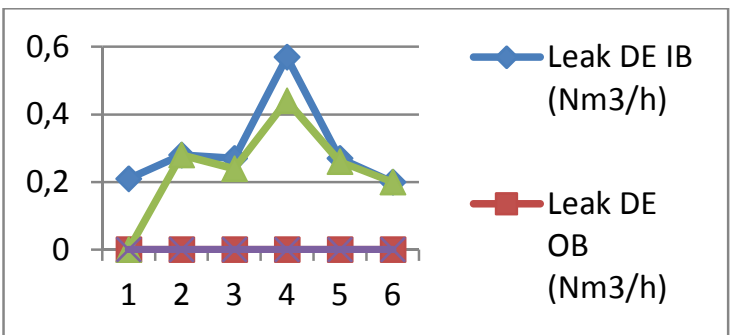

Gambar 11. Tingkat Kebocoran (Leakage) Maksimum Hasil Pengujian

Jadi dari tabel 2 dan gambar 9, 10 dan 11 terlihat bahwa kecepatan maksimum yang dipakai dalam pengujian ini mencapai 11429 rpm, jika dibandingkan dengan prosedur adalah 1 - 1,225 x putaran rpm di kompresor maka di dapatkan putaran menurut prosedur adalah $(1,225 \times 10000=12250 \mathrm{rpm}$ maksimum $)$ dengan kondisi $11429 \mathrm{rpm}$ masih dalam toleransi putaran pengujian.

Untuk pengujian kebocoran menghasilkan maksimum leakage $0,44 \quad \mathrm{Nm}^{3} / \mathrm{h}$ sementara kebocoran maksimum yang diijinkan adalah 3 $\mathrm{Nm}^{3} / \mathrm{h}$. Hasil ini masih di bawah toleransi yang diijinkan.

Dry gas seal beroperasi di bawah toleransi yang sangat ketat yang menuntut agar perhatian khusus diberikan dalam desain lingkungan seal gas, dan dalam pengoperasian kompresor dan sistem seal gas. Sementara ancaman degradasi seal dan pengurangan umur seal karena pengaruh luar adalah nyata, efek merugikan dari faktor-faktor ini dapat diminimalkan. Dengan komunikasi yang tepat antara OEM kompresor dan pengguna selama fase desain, dan dengan pelatihan yang tepat dari operator dan personel pemeliharaan, keandalan dry gas seal dapat dioptimalkan.

Dalam pengoperasian dan pemeliharaan kompresor sertifugal khususnya kompresor gas sering sekali terjadi kerusakan dry gas seal atau meskipun tidak rusak dry gas seal harus tetap di health check agar bisa digunakan dengan optimal dan keandalannya bisa meningkat. Dalam melakukan helth check atau perbaikan dry gas seal salah satu penentu 
keberhasilannya adalah dengan melalui pengujian statik dan dinamis dengan menggunakan DGS test rig atau sejenisnya.

\section{KESIMPULAN}

Dari hasil pengujian yang dilakukan di PT. Fluid Science Dynamics pada tanggal 17 Januari 2019 dapat disimpulkan bahwa kecepatan maksimum yang dipakai dalam pengujian ini mencapai 11429 rpm, jika dibandingkan dengan prosedur adalah 1 - 1,225 x putaran rpm di kompresor maka di dapatkan putaran menurut prosedur adalah $(1,225 \mathrm{x}$ $10000=12250 \mathrm{rpm}$ maksimum) dengan kondisi 11429 rpm, kondisi masih dalam toleransi putaran pengujian (sudah memenuhi standar). Pengujian kebocoran menghasilkan maksimum leakage $0,44 \quad \mathrm{Nm}^{3} / \mathrm{h}$ sementara kebocoran maksimum yang diijinkan adalah 3 $\mathrm{Nm}^{3} / \mathrm{h}$, dan hasilnya masih di bawah toleransi yang diijinkan. Dalam melakukan pengujian perlu diperhatikan tiap parameternya, mulai dari tahap persiapan hingga akhir pengujian. Tidak boleh ada salah satu parameter yang ketinggalan, karena akan mempengaruhi hasil dari pengujian.

\section{DAFTAR PUSTAKA}

[1] Fluid Science Dynamics, 2016, Bahan Training: Compressor Shaft Sealing. PT. Fluid Science Dynamics Indonesia, Tangerang.

[2] Fluid Science Dynamics, 2016. Bahan Training: Gas Seal Technology. PT. Fluid Science Dynamics Indonesia, Tangerang.

[3] Fluid Science Dynamics, 2019, Seal Repair Center: Adding Value to Dry Gas Seal Overhauls, Kaydon ring \& Seal, Inc. USA

[4] John S. Stahley, 2003, Design, Operation, and Maintenance for Improved Dry Gas Seal Reliability in Centrifugal Compressor, Dresser-Rand; Olean, NY, USA

[5] Shah, P., 1988, Dry Gas Compressor Seals, Proceedings of the Seventeenth Turbomachinery Symposium, Turbomachinery Laboratory, Texas A\&M University, College Station, Texas, pp. 133139.

[6] Sedy, J., A New Self Aligning Mechanism for Spiral Groove Gas Seal Stability, A SLE-79LC-3B-3, 1979. 